\author{
Katarzyna Jabłońska-Karczmarczyk \\ The John Paul II Catholic University of Lublin \\ e-mail: katarzyna.jablonska-karczmarczyk@kul.pl \\ ORCID: 0000-0003-3328-7274
}

\title{
DETERMINANTS OF THE COMPETITIVENESS OF THE REGIONS OF EASTERN POLAND
}

\section{WYZNACZNIKI KONKURENCYJNOŚCI REGIONÓW WSCHODNIEJ POLSKI}

\author{
DOI: $10.15611 / \mathrm{pn} .2019 .12 .4$ \\ JEL Classification: R11
}

\begin{abstract}
Summary: The aim of the study is to draw attention to the current processes of adapting regions to the competitive situation. This is related to the globalization process and the disappearance of geographical and economic barriers. As a result, regions must actively monitor the market and respond to changes. The study presents the concept of region's competitiveness, and an analysis of competitive ability factors. The rest of the article is an analysis of the conditions of competitiveness of Eastern Poland voivodeships using the multidimensional comparative analysis method.
\end{abstract}

Keywords: regional competitiveness, multidimensional analysis, factor competitiveness, synthetic measure of development.

Streszczenie: Celem opracowania jest zwrócenie uwagi na aktualne procesy dostosowawcze regionów do sytuacji konkurencyjnej. Wiąże się to z procesem globalizacji i zanikaniem barier geograficznych oraz ekonomicznych. Skutkiem tego regiony muszą aktywnie obserwować rynek i reagować na zachodzące zmiany. W opracowaniu zaprezentowano pojęcie konkurencyjności regionu, przedstawiono również analizę czynników zdolności konkurencyjnej. Dalsza część publikacji stanowi analizę uwarunkowań konkurencyjności województw wschodniej Polski z wykorzystaniem metody wielowymiarowej analizy porównawczej.

Słowa kluczowe: konkurencyjność regionów, wielowymiarowa analiza porównawcza, konkurencyjność czynnikowa, syntetyczny miernik rozwoju.

\section{Introduction}

The period of the functioning of Polish regions as part of EU structures is a time of very dynamic changes that require constant adaptation, including those in the area of improving competitiveness. The signs of this improvement are the implementation 
of investments and new solutions, the successful entry into new markets, and a clear strategy of the region determining its sustainable development. Launched in 2010 and published every three years, the Regional Competitiveness Index (RCI), enables regions to monitor and evaluate their development over time and compare with other regions [Dijkstra et al. 2011, p. 3]. This is the first tool that allows to look at the competitiveness of regions from a European perspective. The inspiration for its creation was the Global Index of the World Economic Forum. Table 1 contains data on the position of individual voivodeships in comparison to EU regions and the position in the country.

Table 1. Position of voivodeships according to the European Index of Regional Competitiveness in 2010-2016

\begin{tabular}{|l|c|c|c|c|c|c|c|}
\hline \multirow{3}{*}{ Voivodeship } & \multicolumn{2}{|c|}{2010} & \multicolumn{3}{c|}{2013} & \multicolumn{2}{c|}{2016} \\
\cline { 2 - 8 } & \multicolumn{5}{|c|}{ Position of the region } \\
\cline { 2 - 7 } & in EU & in Poland & in EU & in Poland & in EU & in Poland \\
\hline Mazowieckie & 159 & 1 & 147 & 1 & 150 & 1 \\
\hline Śląskie & 181 & 2 & 175 & 2 & 170 & 2 \\
\hline Małopolskie & 187 & 3 & 184 & 3 & 171 & 3 \\
\hline Dolnośląskie & 192 & 4 & 190 & 4 & 177 & 4 \\
\hline Pomorskie & 202 & 7 & 194 & 5 & 179 & 5 \\
\hline Lódzkie & 200 & 5 & 197 & 7 & 181 & 6 \\
\hline Wielkopolskie & 201 & 6 & 209 & 11 & 190 & 7 \\
\hline Świętokrzyskie & 232 & 14 & 212 & 13 & 194 & 8 \\
\hline Lubelskie & 227 & 13 & 204 & 8 & 197 & 9 \\
\hline Zachodniopomorskie & 211 & 9 & 207 & 10 & 198 & 10 \\
\hline Lubuskie & 220 & 10 & 206 & 9 & 202 & 11 \\
\hline Podkarpackie & 221 & 11 & 214 & 14 & 204 & 12 \\
\hline Opolskie & 210 & 8 & 196 & 6 & 205 & 13 \\
\hline Podlaskie & 237 & 16 & 211 & 12 & 211 & 14 \\
\hline Kujawsko-Pomorskie & 225 & 12 & 215 & 15 & 211 & 15 \\
\hline Warmińsko-Mazurskie & 235 & 15 & 230 & 16 & 215 & 16 \\
\hline Number of regions covered by the survey: in $2010: 271$, in $2013: 273$, in $2016: 276$ & \\
\hline
\end{tabular}

Source: own study based on EU Regional Competitiveness Index: RCI 2010, EU Regional Competitiveness Index: RCI 2013, EU Regional Competitiveness Index: RCI 2016.

When Poland joined the European Union 15 years ago, five voivodeships of Eastern Poland were the least prosperous regions, not only in the country, but also among all 24 countries of the then European Union. The quality of life of the inhabitants of the Lubelskie, Podlasie, Podkarpackie, Świętokrzyskie and Warmińsko-Mazurskie voivodeships significantly differed from the average standard of living in the EU. This difference was illustrated by the indicator of gross domestic product (GDP) per 
inhabitant, which in 2006 in five voivodeships was slightly above one-third of the EU average. The lower level of economic development was primarily a result of the lack of modern infrastructure that would allow development. The investment needs concerned many spheres of social and economic life. That is why these voivodeships were covered by special additional support from European funds aimed at levelling differences in the level of development between these areas and the rest of the regions. The analysis of data in Table 1 shows that all regions of Eastern Poland have used their opportunity and improved their position in relation to other EU regions. The Index results not only show a change in the competitive position of individual regions, but also how large the diversity of regions is within this macro-region. The Lubelskie and Świętokrzyskie voivodeships have significantly improved their position compared to others in the country over the years, however the position of the Warmińsko-Mazurskie voivodeship deteriorated, as it did for the Podkarpackie voivodeship. This allows to put forward a thesis about the occurrence of certain conditions determining the development of the region's competitiveness. These are the factors that make some regions better use the support received in building their competitive position. The role that Polish regions will play in the European and world economy will depend on their competitive position. It should be emphasized that building a competitive region is not a fast but a long and very complex process. The aim of the presented study is an attempt to formulate an answer to the question of what determines the competitiveness of regions and show the paths to improve the competitive position of regions of Eastern Poland.

\section{Regional competitiveness}

Research on the competitiveness of enterprises, industries, regions and national economies are inextricably linked to the ongoing integration and globalization processes. Competitiveness is a concept often used in literature, but due to its multidimensional character, it is defined differently. The easiest way to define competitiveness is to say that it is the ability to compete. Generally speaking, competitiveness is the ability to achieve one's goals in competing with other market players. Otherwise it can be stated that it is the ability to act effectively in a competitive environment [Urbaniak 2007, p. 245]. In general, competitiveness is a feature that evaluates economic entities from the point of view of achieved results and the ability to achieve them in the future [Bossak, Bieńkowski 2004, p. 18] primarily on the micro, macro (national economies) and on the meso scale (regional economies). The region's competitiveness means, in simplified terms, its ability, measured in relation to other regions, to guarantee a social and economic environment supporting economic activity and the process of raising the overall level of productivity and innovation using internal and external human, financial and material resources. One of the definitions of the region's competitiveness that is most commonly used in the literature is taken from the European Competitiveness Report [European Comission 2006], which states that a region's competitiveness is 
the ability to continually develop and continually improve the living conditions of a given nation while maintaining unemployment at a relatively low level.

At the same time, this is not measurable in a simple and one-dimensional economic category, but rather the effect of combining many measurable phenomena. It can be understood as a set of features determining the attractiveness of the region from the point of view of investment location or as a place of residence, as well as an expression of technological advantage or lower prices of products and services produced in the region in comparison with other regions. The attractiveness of a region is referred to by Kłosiński [2003, p. 9], as competitiveness at regional level which means the ability to attract capital and aid funds and the ability to retain the production factors in the region.

Depending on the research objective, the concept of competitiveness is narrowed down or generalized. There is also a distinction between the concept of competitive position and ability, i.e. result and factor competitiveness, and the ability to compete [Gorynia, 2010, p. 48]. Factor competitiveness distinguishes those elements of the region that provide it with a long-term competitive advantage, such as the ability to exploit the resources of the region, and the speed of response to the transformations taking place in the environment. The resultant competitiveness indicates the effects of competition, i.e. a competitive position which refers to the participation of the economy of the region in international exchange. A change in competitive position occurs when the level and conditions of a given country's or region's participation in international trade alter, because regions compete by creating appropriate development conditions for economic activity. The indicators of improving their competitive position are, among others, an increase in the share in trade or an improvement in the export structure of the region, an increase in the presence of companies with foreign capital in the region - which may indicate an increase in investment attractiveness. Competitive ability, also called factor competitiveness, reflects the long-term ability of the region's economy to meet international competitiveness. It is a derivative of factors such as the size and structure of production factors or the efficiency of their use. Based on these factors, conclusions can be made about the level of competitiveness expected in the future [Gorynia 2010, p. 49]. According to W. Bieńkowski [Bossak, Bieńkowski 2004, p. 30], the measure of the increase in competitive ability is not only the improvement of competitive position, but also the preservation of the region's economy by the ability for a long-term profitable development, which results in the structure of the economy that can adapt to longterm changes in the structure of global demand. Some authors (cf. [Góralski, Lazarek 2009]) believe that when considering the level of competitiveness of regions, attention should be paid to their economic strength. It is estimated that economic strength is determined on the basis of the amount of public revenues created in the regions. Therefore, it is widely believed that the following factors are responsible for competitiveness: diversification of the region's economic structures, communication accessibility and existing scientific and research facilities. 


\subsection{Economy structure of voivodeships}

According to the above approach, the competitiveness of the region and its economic structure are related to economic categories; competitiveness means, among others, ability to modernize economic structures, and in turn modernization of structures which should contribute to increasing the competitiveness of the area. The processes aimed at modernizing regional economic structures have a positive impact on changing the competitiveness of these areas. In the global economy, fierce competition is taking place with everyone, which also forces regions to develop their ability to compete. This ability consists in creating conditions that provide regions with development opportunities, using appropriate instruments that will allow them to achieve their goals at the desired level. Multifunctional regions with a relatively modern economic structure have the greatest chance of joining global competition. Analysis of the indicator of the share of three sectors in employment in individual voivodeships (Figure 1) provides important information on the regional economy. It shows that their economy is very diversified and characterized by high dynamics.

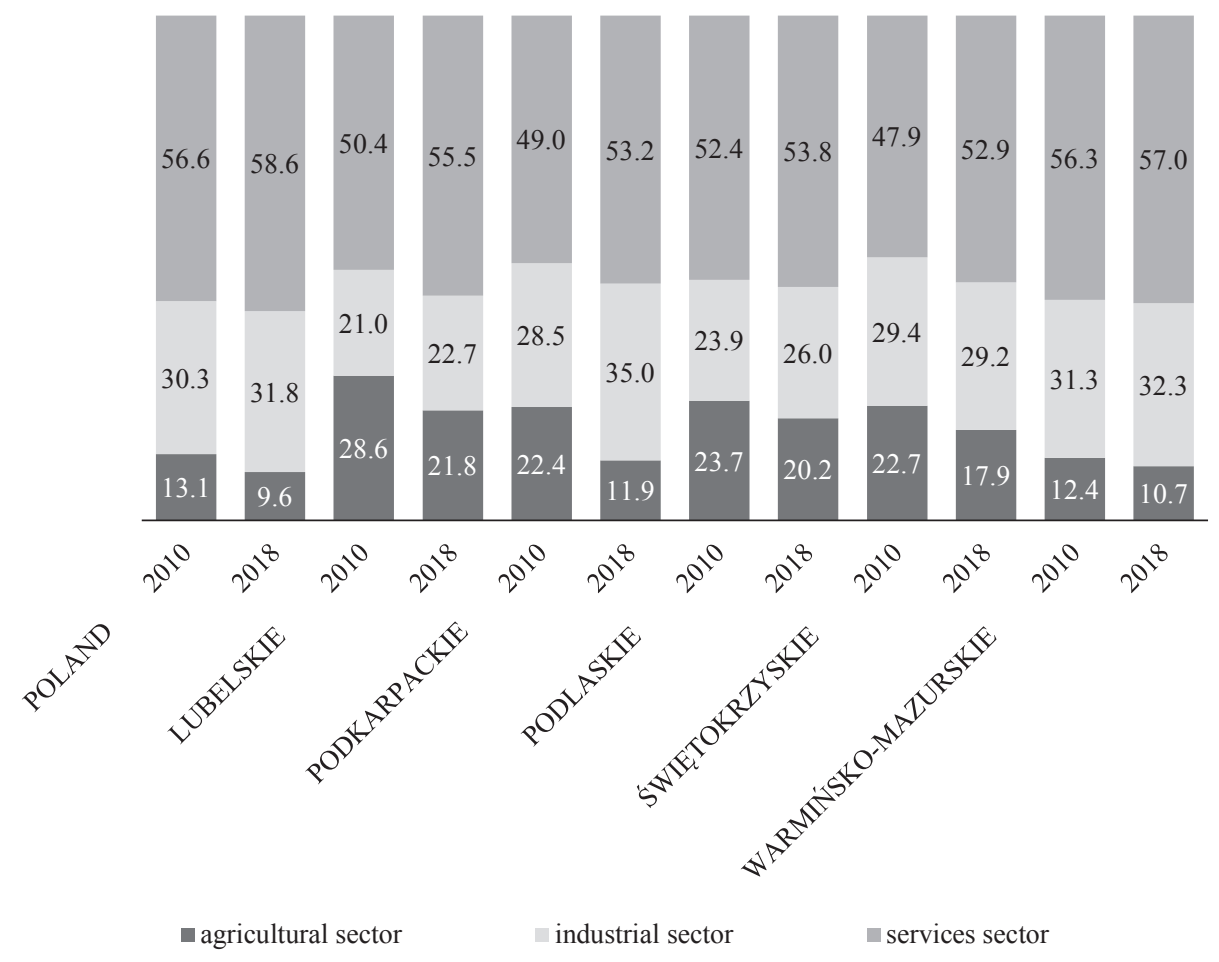

Fig. 1. Structure of employment in three sectors in the economy (in\%)

Source: own study based on GUS data. 
By synthesizing the concepts presented in the subject literature, the region's competitiveness can be defined as its ability to shape the economic structure in a long-term way which guarantees socio-economic development and an increase in the level of real income. A competitive economy structure is one with a large share of the service sector and a small agricultural sector. A characteristic feature of these sectors is their high labour intensity which creates jobs. In addition, service sectors, in particular those of a commercial nature, contribute to the competitiveness of regional economic structures. In better developed regions, one can also note a decrease in employment in trade, transport, hotel and catering in favour of knowledge-based services (related to business, IT and telecommunication). The Warmińsko-Mazurskie voivodeship definitely stands out, where the employment structure has a very high proportion of service sectors. On the other hand, there is a group of voivodeships in which the importance of agriculture is still very high: Lubelskie, Świętokrzyskie and Podlaskie. Particularly noteworthy is the Podkarpackie voivodeship, which alone has significantly reduced the share of agriculture in the employment structure over the years. The region is distinguished by the highest dynamics of the development in IT and ICT services, i.e. knowledge-based, in comparison to the other voivodeships.

\subsection{Investment and innovation activities}

Contemporary regions play the role of entrepreneurial units whose main task is to shape the right climate for business and attract new investors [Gorzelak, Jałowiecki 2000, p. 12]. The above-mentioned definitions reflect a general understanding of the competitiveness and competitive position of regions, but they do not sufficiently emphasize that the competitive advantage of a region in a given field can only be said when there is an above-average concentration of factors in that region compared to other regions of the country or with other countries. One of the most important factors determining this advantage is the potential of the R\&D and innovation sphere.

The changes in competitiveness potential are primarily determined by the intensity of investment activities. Investments (domestic and foreign) are undoubtedly one of the elements influencing the modernization of regional economic structures and an important factor of competitiveness. One of the indicators that allows to notice changes in economic structures is the inflow of capital to regions, including foreign ones. The economic success of regions depends to a large extent on their ability to raise and retain mobile capital, not only foreign but also domestic.

\subsection{Human capital}

The guarantee of durability of a competitive position is increasingly the human capital, while the quality of this capital depends on the entire educational and research infrastructure. The current high level of technological advancement in the region without the $R \& D$ base, technology transfer system and implementation of innovation is not able to provide the region with a high level of competitiveness in 
the long term. The region's economic growth as a result of expenditure on innovation and research and development activities can only be achieved if the reported demand for the human resources is satisfied. In addition to the basic indicator, which is the percentage of professionally active population, the level of qualifications of this group or its potential is important.

\subsection{Transport accessibility}

Transport accessibility can be used in various contexts, e.g. in relation to the transport network, various types of services, as a factor in the economic development of regions and their competitiveness, as well as a factor in the location of economic activity [Koźlak 2012, p. 172]. Transport accessibility is an important element of the organization of space, with a significant impact on the diversity of functionalities of individual regions. The better communication accessibility, the better the potential conditions for economic development and for raising the level and quality of life of its inhabitants. An increase in availability can cause many interactions, for example, modernization of existing transport infrastructure in a given area may generate larger traffic flows and has a significant impact on the development of areas around modernized sections of the transport network. Accessibility is also one of the basic components determining the investment attractiveness of a given area. One can distinguish many methods of testing transport accessibility, the most common choice is the potential availability measured by technical infrastructure, e.g. the length of expressways.

\section{Methodology}

The situation regarding the conditions of competitiveness of regions and their changes was characterized based on secondary data from the Central Statistical Office's resources. The research was carried out for 2010-2017. The positive development pattern method was used to assess the conditioning of regional competitiveness.

The development pattern method used is a linear ordering method. The goal of linear ordering methods is to rank objects in order from best to worst, and the ordering criterion is the level of the complex phenomenon. The specificity of the methods of ordering a linear set of objects among the methods of multi-criteria comparative analysis is that it is necessary to determine the nature of all variables describing the studied complex phenomenon. In the development pattern method, it is assumed that the values of variables are normalized and have the character of a stimulant or destimulant.

In the first stage of research, features describing the phenomenon under study were selected. Not all features are equally important from the point of view of the subject of the study and not all should be included in further analyzes, and the selection of variables for the set of diagnostic features was made using the variability 
criterion. To assess competitiveness conditions, those indicators were selected whose values showed sufficient spatial variability (coefficient of variation $>0.1$ ).

As a result, an $\mathrm{X}$ matrix of observations made on variables describing an individual voivodeship was obtained:

$$
X=\left[x_{i j}\right],(i=1,2, \ldots, n \quad j=1,2, \ldots, m),
$$

where: $n$ - number of voivodeships, $m$ - number of variables.

The next stage was to bring all variables to the form of stimulant and normalize the values of these variables according to the formula:

$$
z_{i j}=\frac{x_{i j}-\overline{x_{j}}}{S_{j}}
$$

Then a weight system for diagnostic variables was created. It was assumed that the variables with the greatest variability (those that differentiate the phenomenon to the greatest extent) will receive the highest weights. The following formula was used to calculate the weight system:

$$
w_{j}=\frac{V_{j}}{\sum_{j=1}^{m} V_{j}}
$$

where: $w_{j}$ - weight assigned to the $j$-th variable, $V_{j}$ - coefficient of variation of the $j$-th variable before standardization.

In the next stage, an abstract object was designated, the so-called z0 development pattern with the best values for each variable. The object's similarity to the abstract best object was then examined by calculating the distance (e.g. Euclidean) of each object from the development pattern.

$$
d_{i}=\sqrt{\sum_{j=1}^{m} w_{j} \cdot\left(z_{i j}-z_{0 j}\right)^{2}},
$$

where: $z_{0 j}=\max \left\{z_{\mathrm{ij}}\right\}-$ reference object.

The final stage was the normalization of the synthetic development measure. As a result of the transformations of measures, the distances took values from 0 to 1 and their increase corresponded to the more favourable development of the analysed phenomenon.

$$
z_{i}=1-\frac{d_{i}}{d_{0}}
$$

where: $z_{i}$ - a synthetic measure of development for the $i$-th object, $d_{0}-$ a norm ensuring that values from 0 to 1 are taken by and calculated according to the formula: 


$$
d_{0}=\bar{d}+2 \cdot S_{d}
$$

$\bar{d}$ - arithmetic mean of the variable $d_{i}, S_{d}$ - standard deviation of the variable $d_{i}$.

The development measure is structured to meet the following properties: the higher the level of the complex phenomenon, the higher the value of the measure of development; the values of the development measure are included in the range [0,1], with the development measure calculated for the development pattern equal to 1 for the anti-predictor 0.

An important advantage of this method is that it allows one to directly assess several (or more) statistical units. The same standards and normalizing factors are introduced. Therefore, distances are calculated from the same point and then reduced to an equal scale. Then, using the results obtained after calculations using this method, the units were classified in terms of competitive conditions.

\section{Findings}

There are as many different definitions of competitiveness, as there are many different methods and indicators of measuring competitiveness The measurement of competitiveness should take into account social and economic factors. Competitiveness conditions listed in the theoretical part, such as the structure of the region's economy, investment and innovation activities, communication accessibility, have been included in the research part using appropriate variables (Table 2).

Table 2. Description of variables used in the analysis

\begin{tabular}{|c|c|}
\hline Variable & What does it reflect? \\
\hline share of the agricultural sector in the economy & \multirow[t]{2}{*}{ level of development of the region's economy } \\
\hline capital expenditure per capita & \\
\hline $\begin{array}{l}\text { number of patents granted per } 100,000 \\
\text { population }\end{array}$ & \multirow[t]{2}{*}{ region's innovation potential } \\
\hline $\begin{array}{l}\text { expenditure on research and development per } \\
\text { capita }\end{array}$ & \\
\hline $\begin{array}{l}\text { economic activity of the population } \\
\text { (\% of population) }\end{array}$ & \multirow[t]{2}{*}{$\begin{array}{l}\text { human capital } \\
\text { quality of human capital }\end{array}$} \\
\hline university students per 10,000 population & \\
\hline hard surface roads per $100 \mathrm{~km}^{2}$ & \multirow[t]{2}{*}{ transport accessibility of the region } \\
\hline expressways and motorways per $100 \mathrm{~km}^{2}$ & \\
\hline
\end{tabular}

Source: own study.

Then the indicators were used to determine a synthetic measure of development. The advantage of this method is that as a result one synthetic variable is obtained, which shows the direction and size of changes occurring in the processes described by 
any number of sets of diagnostic variables, and at the same time allows an objective assessment of these transformations. The values of the synthetic development pattern for the surveyed companies are presented in Figure 2. The meter assumes values from 0 to 1 . The closer to 1 , the better the competitive position of the enterprise.

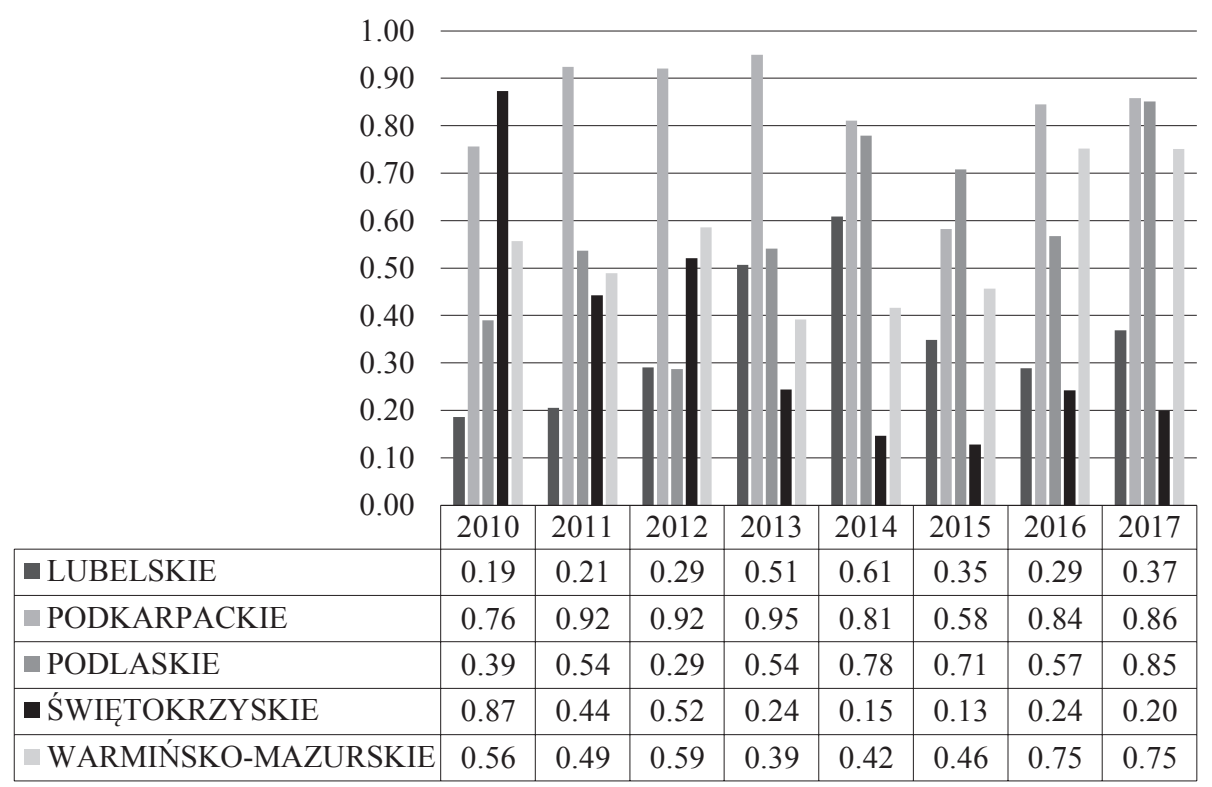

Fig. 2. The values of the synthetic measure of development for the examined voivodeships in 2010-2017

Source: own study based on GUS data.

Data analysis shows that the leader in terms of the value of the indicator of the synthetic development pattern throughout the entire research period is the Podkarpackie voivodeship, achieving the results nearest to 1 . When assessing the entire research period, it should be noted that the first position changed: in 2010 it was held by the Świętokrzyskie voivodeship, and in 2017 by Podkarpackie. The position of the Podkarpackie voivodeship was to the greatest extent determined by these three elements: investment activities, human capital and transport accessibility. Additionally, as the only voivodeship examined, it significantly improved the structure of the economy, i.e. it decreased the share of the agricultural sector in favour of the services sector in the employment structure.

The weakest position in the context of these competitiveness factors in the surveyed group in 2017 was occupied by the Świętokrzyskie voivodeship. One of the reasons was investment expenditure, although its volume increases every year, but when compared to other voivodeships they are insufficient. Considering the 
results from 2010 and 2011 this is a big decrease, which means weakening the ability to participate in the competition of regions both at present and in the future.

The Podlaskie voivodeship stands out positively, which in truth is not a leader, but has significantly improved its position: from being fourth in 2010 to second in 2017. This change is due to growing investment outlays.

The one-dimensional indicator analysis presented in the paper did not give an opportunity to assess which voivodeships in relation to the others are characterized by better conditions for the development of competitiveness. Only the use of multivariate comparative analysis allowed the transformation of multivariate variable space into one-dimensional synthetic variable space. The synthetic measure of development obtained in this way provides information about the direction and size of changes taking place in the conditions of competitiveness of voivodeships. All the factors affecting competitiveness should be analysed together. The high level of one of them with the low level of the other does not allow a positive assessment of the development conditions of individual provinces. Only by using appropriate weights (depending on the degree of variability of the examined feature), was it possible to develop a method for assessing conditions in relation to various factors, such as communication accessibility or the structure of the regional economy.

In the group of analysed voivodeships there is a clear differentiation, the leader position of the SMR indicator is close to 1, While other positions from 2 to 5 are variable.

\section{Conclusion}

Regional competitiveness means the ability of regions to adapt to changing conditions in terms of maintaining or improving their position in competition between regions. The region's potential for competitiveness is largely the result of the volume and structure of past investments. In the last decade there has also been a large variation in the level of development within macroregions. Regions often do not form a compact whole, and their elements develop at different rates and with varying intensity, and eastern Poland voivodeships are an example of this. All development processes occurring in the regions are characterized by high complexity, which is why isolating the basic factors as well as determining their impact on competitiveness is very complicated. This difficulty lies in measuring the intensity and direction of impact of each of the factors. 


\section{References}

Bossak J.W., Bieńkowski W. (2004), Międzynarodowa zdolność konkurencyjna kraju i przedsiębiorstw. Wyzwania dla Polski na progu XXI wieku, SGH, Warszawa.

Dijkstra L., Annoni P., Kozovska K. (2011), A New Regional Competitiveness Index: Theory, Methods and Findings, Working Papers, no. 2, Directorate-General for Regional Policy, European Union.

European Commission (2006), European Competitiveness Report 2006.

Gorynia M. (2010), Teoretyczne aspekty konkurencyjności, [w:] Gorynia M., Łaźniewska E., Kompendium wiedzy o konkurencyjności, PWN.

Gorzelak G., Jałowiecki B. (2000), Konkurencyjność regionów, Studia Regionalne i Lokalne, no. 1.

Góralski P., Lazarek M. (2009), Czynniki ksztattujace konkurencyjność regionów, Zeszyty Naukowe SGGW, Polityki Europejskie, Finanse i Marketing, no. 1(50).

Kłosiński K. (2003), Konkurencyjność gospodarek narodowych, Handel Wewnętrzny, no. 4-5.

Koźlak A. (2012), Nowoczesny system transportowy jako czynnik rozwoju regionalnego w Polsce, Wydawnictwo Uniwersytetu Gdańskiego, Gdańsk.

Urbaniak W. (2007), Konkurencyjność - próba zdefiniowania zjawiska, Acta Universitatis Lodziensis. Folia Oeconomica, no. 204. 